特集一デザイン

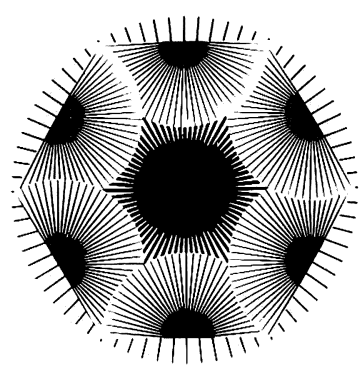

\section{デザインにおけるコンピュー 夕利用}

\section{神沼 二真}

Tsuguchika Kaminuma，(財) 東京都臨床医学総合研究所

\section{CAD と CAM}

デザインの問題にコンピュータを利用するという話 をするならまず CAD (computer aided design) と CAM (computer aided manufacturing) について述 べなければならないだろう ${ }^{1 \mathrm{a})}$.普通両者を一緒にして $\mathrm{CAD} / \mathrm{CAM}$ とつづける.

ただしここでいうデザインとは，あくまでも機械, 自動車, 航空機など, 工学的な構造体のデザインのこ とである，大雑把な計画図から，基本設計図，詳細設 計図と，構造体を作るための図面はだんだん細かく展 開されるが,このデザイナーの仕事を助けるのが CAD である。逆に，最も詳しい工作図から部品を作り，こ れを組み合わせて，ひとつの構造体を完成する製造部 門を支援するのがCAM である．昔から，デザイナー と製図とは切っても切り離せない関係にあったが，今 ではデザイナーは製図板に向かわず，図形処理を得意 とするコンピュータディスプレイに向かって仕事をす る.

このような CAD/CAM システムは, 純粋な機械工 学以外の分野でも使われるようになってきている．例 えば, 半導体の集積回路, LSI の回路デザインがそれ である。ここでは, ある諭理的な操作を実行する電子 回路図を展開し，実際の製造工程図に展開するという 仕事で LSI デザイナーを助けることになる。

これらは主として図形を使う仕事である。そのため にコンピュー夕は, 線図, 曲線, 曲面, 3 次元物体 (ソ リッドモデル) などを, デザイナーの求めに応じて生 成し，組み合わせ，できた図をデータべー、スに管理し ておく機能が必要になる。またこ㣗らの処理は，デザ イナーとの対話で行なわれるから，僾れた対話処理機 能が必須となる.

Computer Applications to Macromolecular Design

\section{2. $\mathrm{CAE}$ への発展}

$\mathrm{CAD} / \mathrm{CAM}$ システムが, 普及するにつれ, CAE (computer aided engineering) という概念が登場して きた。例えば，ある機械部分や建物の形をデザインし たとしても，その力学的特性を調べてみなければ，製 作はできない，そこで，例えば有限要素法にもとづく， 力学的な構造解析プログラムを用いて, 振動特性や強 度を計算することになる，つまり，形だけでなく物理 的な内容をシミーレートする過程が存在する。つまり，

(1) 仮想的な構造体のデザイン

(2) その性質の吟味

(3) その製造（試作） をすべて含んだ，設計支援システムが求められる.

こうすれば，実際にそれの構造体を試作して，失敗 を繰り返すという手間が省ける。例之ば，昔は飛行機 なら，風洞実験や実物破壊実験による強度テストが行 なわれた，実体モデルや試作機を用いたそうした試行 錯誤過程が全く不要になったわけではないが, 少なく ともコンピュータによって手間は相当省ける。これが CAE の概念である.

というわけで，化学の世界でも CAE の概念を振り まわす人々が出てきた，例えば，数年前筆者らの研究 会（現在の「計算機と化学・生物学の会」）などの活 動を取材して，ケミストリーにも CAE 時代来ると宣

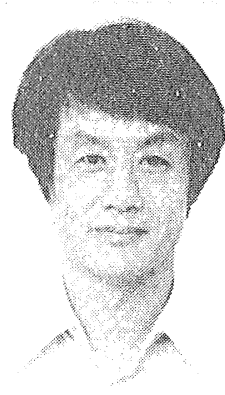

神沼二真 (財) 東京都臨床医学 総合研究所 (113 東京都文京区 本駒込 3-18-22) Ph. D. 昭和 39 年国際キリス卜教大卒, $41 \sim 45$ 年米国イエール大, 八ワ イ大留学. 41 年 46 年ハワイ大 助手, 助教授. 46 年 51 年日立 システム開発研究所研究員, 51 年より東京都臨床医学総研勤 務. 


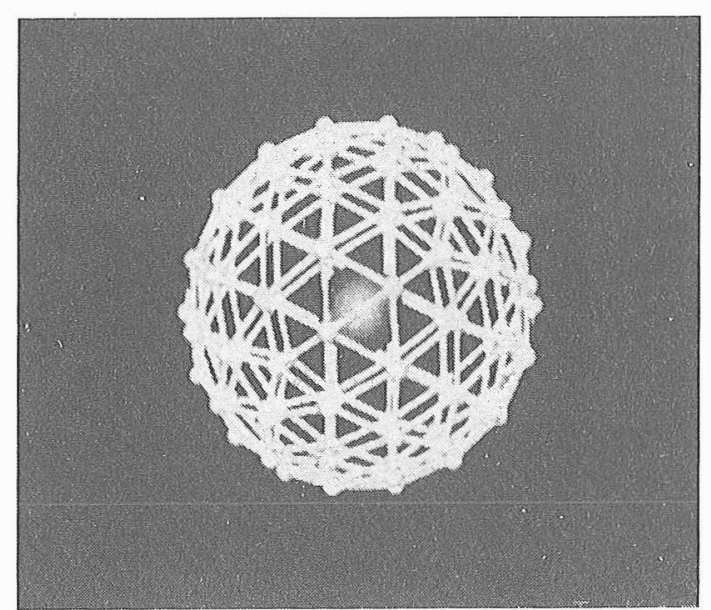

写真 1 分子グラフィックスによる表現 （鈴木 勇氏作製，以下同じ）

伝してくれたコンピュータ関係の雑誌記者氏がいた. その故か，その後のコンピュータ導入の動き，とくに 国のプロジェクトで，CAE を強調する傾向が見られ る1b). しかし, 化学の世界で求められているシステム は，CAEとは程遠い概念のシステムである。これは重 要な点なので, 次に説明しておきたい.

\section{3. 研究者の発想}

いわゆるドラック・デザイン，分子設計，タンパク 質工学などとよばれている分野が，これまで紹介した $\mathrm{CAD} / \mathrm{CAM}$ ，あるいは $\mathrm{CAE}$ と決定的に違うのは，前 者が未知な構造体を相手にしているということであ る。

機械とか, 自動車や飛行機などは, デザインすると 言っても，すでにあるお手本を多少手直しする程度の 知的な作業である，それに対して，化学の研究者が相 手にしているのは，人間の五官で把えられないミクロ の対象物であり，場合によっては機能さ之何んの手掛 りもない．まずどのような分子を候補に立て，その構 造と機能の関係を吟味するかという最初の発想が非常 に重要である.

また，そもそも分子の構造を決定するという仕事も 大変難しい仕事である。とくに, 結晶化が困難な生体 高分子となると，それだけでひと仕事である。ささらに 機能と言っても複雑であり，とても有限要素法で構造 解析をするというような，簡単なことではすまされな い.これが, 高層建築や, 新車が作られるペースで, 新 しい素材や医薬品が登場してこないひとつの理由であ る.

すなわち CAD/CAM，CAEは開発・製造の仕事を 効率化するシステムであるのに対し，分子設計のため

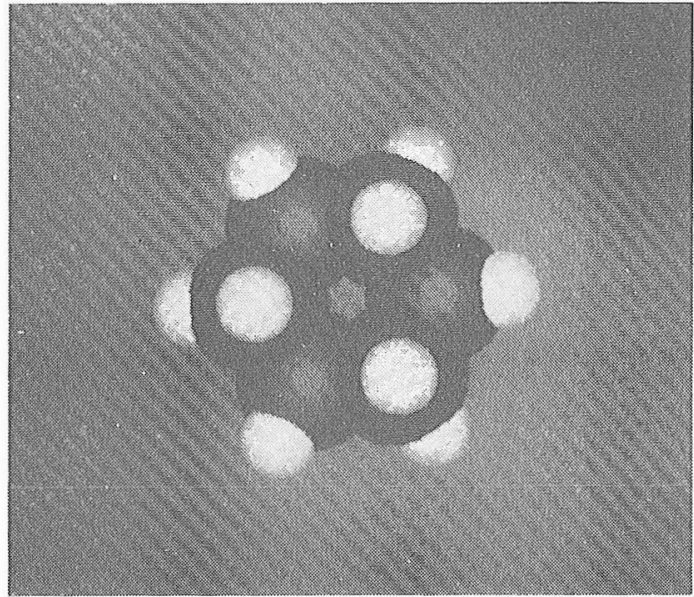

写真 2 シクロヘキサンの分子グラフィックス

のコンピュータは，研究者の創造的思考過程を支援す るものでなければならない。もちろん，機械設計にも， 異なった創造性やヒラメキが必要とされるので，創造 性の点で優劣はつけ難い.しかし双方が必要とするシ ステム，その概念は明らかに異なるのである。

したがって，高分子デザインのためコンピュータシ ステムは, 高分子研究のためのコンピュータという広 い概念として把えた方がよいと思う。

\section{4. 高分子研究支援システム}

それでは，高分子研究を支援するためのコンピュー タとは、いかなるシステムであるべきか？筆者自身は， 高分子の研究者でないので，自信のある答えはできな い.しかし，一応次のような要素システムは必要とな るであろう。

(1) X 線構造解析用システム

(2) 分子グラフィックスとダイナミックス（シミ+ レーション）のためのシステム

(3) 構造と機能を解析するためのシステム

(4) 有機合成支援システム

(5) 構造, 物性, 生物活性（薬効と毒性）などのデ ータベースあるいは知識ベース

(6) 遺伝子工学支援システム

これらの要素システムは，互いに梁く関連し合って いる.そこで中心になるのは，やはり分子構造のモデ 儿的表現とそのダイナミックスの解析であろう.

分子のコンピュータによる表現技法は，今日それだ けで独立して, 分子グラフィックス (molecular graphics）とよばれている2,3). しかし，分子はもともとミ ク口な対象物であるから，構造と言っても始めから明 らかな構造が存在するわけではない，原子半径，原子 


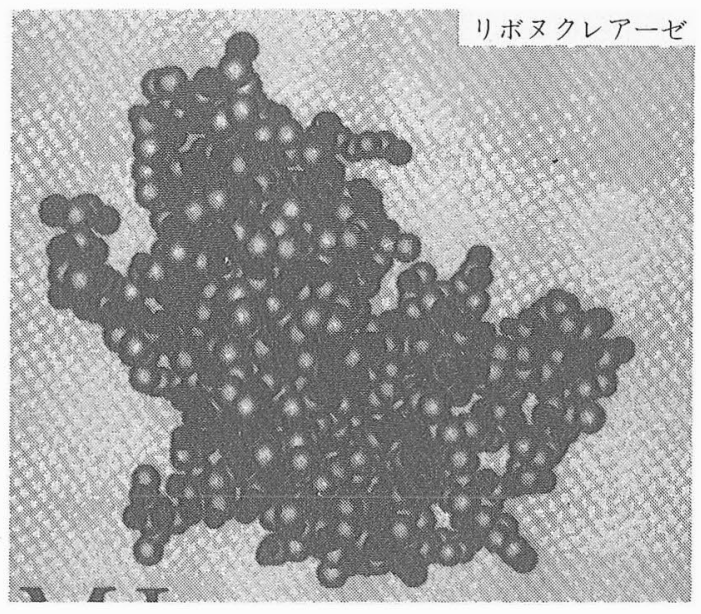

写真 3 タンパク質グラフィックス

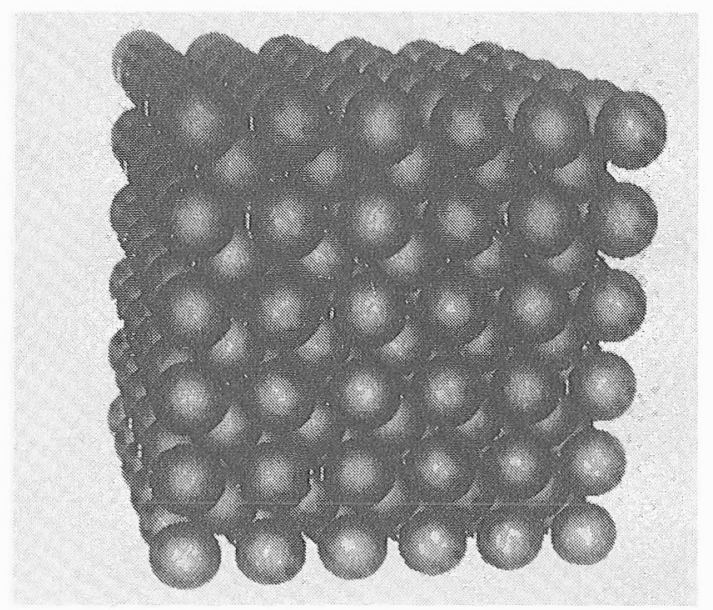

写真 4 分子のパッキングのグラフィックス
間距離から, 結合の回転角, 電子密度, 熱振動, 電荷 分布, 疎水性・親水性など, 考慮すべき要因は少なく ない，ダイナミカルなモデル表現にも左右される，結 局，何をどのように表現するかは，研究の目的と研究 者のイメージによって決定されるべきものである，た だそうは言っても，現実に化学者は，永年，針金モデ ル, 棒と球モデル, 空間充てんモデルなどに親しんでき た.コンピュータの表現もそれに準じたものが多い.

分子グラフィックスの先駆者として知られているの は, N. $\mathrm{Max}^{4)}, \mathrm{R}$. Feldman, R. Langridge ${ }^{5)}, \mathrm{G}$. Marshal ${ }^{6)}$ らである. 先に述べたように,この種のシス テムは, 単独では意味がない, 最も関係深いダイナミ ックスのプログラムとしては, 分子力学 (molecular mechanics) や, 分子軌道法 (molecular orbital calculation) にもとづく, 配座解析 (conformational analysis) がある.これには A.J. Hopfinger と R. Potenzone らの CHEMLAB の完成度が高い7)

上記 (1) (4) のすべての要素プログラムを統合した ものとしては, D. Pensak らが開発した Du Pont 社 の TRIBBLE ${ }^{8)}$, M.K. Huber, D. White らの Ciba Geigy")のシステムがある.ただし，これらは化学研究 システムであり, 遺伝子工学支㩖システムは含まれて いない

\section{5. 生物による高分子の合成}

人為的な核酸の塩基配列を青写真として, 微生物に タンパク質を合成させるいわゆる遺伝子組み換え技 術, あるいは選択的結合性に優れたモノクロナール抗 体を工業的に利用することへの関心が高まっている.

まず構造が既知のタンパク質から出発して，アミノ 酸の 1 部を遺伝子組み換えによる変異で置換して, そ
の機能を強化あるいは低下させるという，いわゆる夕 ンパク質工学の成功例 ${ }^{10)}$ が, いくつか報告されるよう になってきた。もちろん，アミノ酸をもっと大規模に 変えたり, 全く新しいタンパク質を 1 次構造配列から デザインすることも将来の夢として残されている.

このような新しい高分子のデザインには, 核酸や夕 ンパク質配列構造の解析を主とする, いわゆる遺伝子 工学支援プログラムが必要になってくる，ここで最も 重要なのは,

(1) 配列 (1 次構造) の相同性（相似性）を調べる, 木モロジー検索と，

(2) 1 次構造から 2 次あるいは, それ以上の高次構 造の推定

である、いずれも，計算法自身が簡単でない上に，計 算に要する時間も馬鹿にならないため, 現在も盛んに 研究されている.

タンパク質の機能はその構造と深く結びついている から，ここでも分子グラフィックスが必須となる。こ れまで, 分子モデリングやグラフィックスのコンピュ 一タシステムと, 配列解析プログラムは, ほとんど独 立に開発され，使われてきたが，タンパク質工学にお いては，再者は関連して使われるようになってきたの である。

タンパク質の 1 次構造から高次構造推定は, より一 般的に言えば，1次元ポリマーのデザインの問題と言 うことができる.アミノ酸の配列から,タンパクの 3 次 構造を計算で求めることは, ほとんど不可能に近いほ ど難しい.しかし，アミノ酸より簡単な基本分子が重 合したポリマーなら，その構造をある程度推定するこ とも夢ではないであろう。 


\section{6. 分子集合体のデザイン}

個々の分子の合成の次にくる問題は，当然分子の集 合体のデザインである。ひとつの具体例は，バイオ素 子の開発である。バイオ素子とは，ここではタンパク 質のような有機分子を構造要素とする, 電子回路素子 を意味する ${ }^{11,12)}$. これは現在の半導体集積回路に代わ る, 超高密度電子回路や, 光電変換機能を有する視覚 センサーや，化学物質を検出する化学センサーの基盤 的技術として注目されている.

このような方向への第 1 ステップは, LB (Langmuir-Blogett) 膜法による薄膜形成である.ここで, 2 次元の膜構造における分子の配列を制御することが問 題となる. Genex というベンチャ一企業で, タンパク 質工学を提唱し，その後 Maryland 大学に移った K. Ulmer は実際この問題に取り組み，もとになる分子の 立体構造を適当にデザインすることにより，規則正し い2 次元分子膜を形成できることを確かめている。こ の時, 彼らは分子グラフィックスで, 分子の立体構造 を吟味しただけでなく，できた 2 次元構造膜を電子顕 微鏡写真に取り，それをコンピュータで処理して，正 しい構造であることを確かめている，後者は一般に空 間フィルターによる画像処理という技術であり， A. Klug らによって結晶化しない生体高分子の構造解析 に適用されて成功を収めた手法である ${ }^{13)}$.

このほかに，3 次元 LSI や液晶なども，分子集合体 のデザインの問題である．このような問題にコンピュ ー夕をどう役立てるかは, 将来の課題である。

\section{7. 生命のデザイン}

分子集合のデザインの次にくるのは, 生命のデザイ ンであろう。例えば簡単な多細胞動物のデザイン，人 間の臓器の再生デザイン, 培養神経細胞を回路状に結 線すること。これらは遠からず工学の問題になるであ ろう.

この方向への第一歩は, 生物の 3 次元的な構造を決 定することである，例之ば，筆者らは線虫の受精卵の 胚発生過程における細胞の空間的配位を時間的に追跡 している.我々はこれを結晶解析 (crystal graphy)に 習って, 細胞配位解析 (cytography) とよんでいる ${ }^{14)}$. また, S. Levinthal らは, 連続した神経標本切片の電 子顕微鏡の写真から, ニューロンの 3 次元的配線構造
を決定する仕事をしている ${ }^{15)}$ ここれらは,いずれも 2 次 元映像からの 3 次元像の再構成 (reconstruction) と よばれる問題であり，画像を解析したり，合成したり するコンピュータの存在が前提になる.

このようにみてくれば，デザインの問題には，さま ざまな部分システムがそろっていなければならないこ とがわかる，そのような統合システムはまだ存在しな いようであるが,これから開発されるであろう。 MINERVA とよんでいる筆者らのシステムは, デー 夕解析, 画像解析, 各種の分子グラフィックス, 遺伝 子工学支㩖システム, cytography 用の実験システムな どきわめて総合的な機能を有しており, 将来の統合シ ステムのプロトタイプと言えるであろう。

将来の統合システムは，おそらく部分システムを強 力な LAN (local area network) で結合したものであ ク, またいわゆる人工知能と称される, 演繹的推論シ ステムを，部分システムとしてもつことになろう!!

\section{文献}

1) a. NICOGRAPH' 84 会議録, 日本コンピュータ グラ フィックス

b. 分子設計・ 反応設計 CAD システム技術に関する調 查研究, 工技院化学技術研究所, 1984

2) 鈴木 勇: 分子グラフィックス（神沼編,生物化学素子 とバイオコンピュータ，サイエンスフォーラム) (1985) p.222

3) 神沼二真: 有機合成化学協会誌, 42, 738 (1984)

4) N. Max: Comp. and Chem., 5, $19 \cdot(1981)$

5) R. Langridge, et al.: Science, 211, 661 (1981)

6) G. Marshal, et al:: ACS Symposium 112, (1979) p. 205

7) A.J. Hopfinger, R. Potenzone, Jr: The Chemical Modelling Laboratory User's Guide (1982)

8) D. Pensak: TRIBBLE Users Mannual, Du Pont (1985)

9) 神沼二真編：バイオテク/ロジーとコンピュータ利 用, シーエムシー (1985) p.235

10) K.M. Ulmer: Science, 219, 666 (1983)

11) F.L. Carter : Molecular Electronic Devices, Marcel Dekker (1982)

12）新機能素子研究開発協会：Proc. Bioelectronic and Biomolecular Electronic Devices (1985)

13）例之ば, P.N.T. Unwin, A. Klug: J. Mol. Biol., 87, 641 (1974)

14）三輪錠司,神沼二真: 線虫を用いた発生・形態形成の研 究（神沼編, 生物化学素子とバイオコンピュータ, サイ エンスフォーラム) (1985) p.191

15) I. Solbel, S. Levinthal, E.R. Macagno: Ann. Rev. Bioeng., 9, 347 (1980) 